\title{
Sociobiology
}

RESEARCH ARTICLE - ANTS

\section{Red Imported Fire Ant Invasion Reduced the Populations of Two Banana Insect Pests in South China}

L WANG, Z WANG, L ZENG, YY LU

College of Agriculture, South China Agricultural University, Guangzhou, P.R. China

\author{
Article History \\ Edited by \\ Evandro Nascimento Silva, UEFS, Brazil \\ Received 29 March 2016 \\ Initial acceptance 07 August 2016 \\ Final acceptance $\quad 12$ September 2016 \\ Publication date 25 October 2016

\section{Keywords} \\ Solenopsis invicta, ecological effect, banana, \\ Erionota torus, Stephanitis typical. \\ Corresponding author \\ Yongyue LU \\ South China Agricultural University \\ 526 College of Agriculture, 483 Wushan Road \\ Tianhe District, Guangzhou, Guangdong \\ China, 510642 \\ E-Mail: luyongyue@scau.edu.cn
}

\begin{abstract}
As a severe invasive pest, red imported fire ant (Solenopsis invicta Buren) had important effects on ecosystem of its infected areas. Here, we surveyed the impact of $S$. invicta on populations of two banana insect pests, banana skipper (Erionota torus Evans) and banana lacebug (Stephanitis typical Distant). The results showed that influences of S. invicta on the populations of E. torus and S. typical depend on weed coverage degree of banana plantations. Comparing to the areas without $S$. invicta, banana skipper population was reduced by $39.2 \%, 41.4 \%$ and $23.4 \%$ respectively, in high, moderate and low weed coverage of banana plantations with S. invicta invasion. Banana lace bug population was reduced by $17.8 \%, 43.0 \%$ and $39.2 \%$ respectively, in high, moderate and low weed coverage of banana plantations with $S$. invicta invasion.
\end{abstract}

\section{Introduction}

As a famous invasive pest, red imported fire ant Solenopsis invicta preyed on many different kinds of invertebrates at different developmental stages including egg, larvae, pupae and adults (Stiles \& Jones, 2001), and caused a sharply decline on populations and diversity of invertebrates and some epigeous vertebrates in its introduced areas (Cook, 2003; Morrison, 2002; Wojcik et al., 2001). However, S. invicta also is an active and efficient predator of pests. $58 \%$ $85 \%$ cotton boll weevil (Fillman \& Sterling, 1983) and 85\% tobacco budworm (McDaniel et al., 1981) were consumed by S.invicta in investigated fields. Vogt et al. (2001) showed that $S$. invicta preyed on about seven times more pest arthropods than beneficial arthropods in peanut field. In Florida, $S$. invicta preyed on eggs and larvae of soybean armyworm (Anticarsia gemmatalis). S. invicta also reduced population of diamondback moth and leaf beetles in collards (Harvey \& Eubanks, 2004). Accordingly, Harvey and Eubanks (2004) believed that $S$. invicta may be particularly important biological control agent in agroecosystems.

Banana is an important economically crop in south China. In China, the most economically damaging pests of banana are Odoiporus longicollis Olivier, Pentalonia nigronervosa van der Goot, Erionota torus Evans, and Stephanitis typical (Lu et al., 2002). E. torus is a phytophagous lepidopteran that feeds on banana plants leaves. E. torus curled up banana leaves and took them as pupation sites (Lu et al., 2002). Nymphs and adults of $S$. typical feed on phloem sap of banana plant and also are vectors of banana rosette dwarf disease which causes serious damage of banana production (Zhou et al., 1993).

In South China, 10-50\% banana plants were infected by S. typical and E. torus in banana garden (Lin et al., 2009; Guo et al., 2012). Although conventional pesticides still are the primarily method for these pests control, integrated pest management (IPM) and biological control are essential for the control of banana pests because many people are concerned about the pollution of the environment and food security issues. 
Since it was detected in mainland China at 2004 (Zeng et al., 2005), S. invicta has been found in many habitats including banana plantation. Harvey and Eubanks (2004) indicated that increasing habitat complexity can enhance $S$. invicta efficacy and herbivore control. So, S. invicta may be a potential effective predator of banana pests because banana plants are often grown in complex, intercropping systems in China (Liu et al., 2015; Ke et al., 2012; Chen et al., 2008). The goal of our study is to assess the effect of $S$. invicta on population of S. typical and E. torus. Meanwhile how habitat complexity affects $S$. invicta predation of $S$. typical and $E$. torus was also evaluated.

\section{Materials and Methods}

\section{Experimental plot and habitat conditions}

The experimental plots located in the banana plantation of South China Agricultural University Ningxi teaching and study training center, Guangzhou, China. The banana plantation (total area of 3.5 acres, and 1.3 acres selected for experiment) was newly established and was in good ventilation and less external disturbance. In this study, dwarf banana was planted which is a hybrids cultivated variety of genus Musa planted widely in south China.

Based on weed coverage, experimental plots were divided into high weed coverage plots, moderate weed coverage plots, and low weed coverage plots. Depend on our investigations (Fig 1), the S. invicta infestation level of all three types of experimental plot are high degree due to the density of fire ant mounds was $7-10$ per $100 \mathrm{~m}^{2}$, and $100-200$ workers in each bait trap in each experimental plot before experiment was conducted (Wang et al., 2009). Plots with high weed coverage and without $S$. invicta were taken as control. Each type of plots was consisted of 6 small plots ( $2 \mathrm{~m}$ width $\times 70 \mathrm{~m}$ length), and they are separated by water drain way (Fig 1).

In this study, high weed coverage was defined as weed was allowed freely growth and more than $70 \%$ of plot area was covered. Moderate coverage was defined as weed was partially removed periodically and $30-70 \%$ of plot area was covered. Low coverage was defined as weed was rooted out often and less than $30 \%$ of plot area was covered. The microclimate, soil condition and ecological environment in all plots were basically similar, and main weed species in our study sites are Cynodon dactylon, Cyperus exaltatus and Cirsium setosum.

\section{Experimental methods}

S. invicta colonies in our study sites were polygyne. The abundance of $S$. invicta in experimental plots was surveyed once in the middle of each month during May to October in 2008 by bait traps ( $\mathrm{Lu}$ et al., 2012). Meanwhile, the number of $S$. invicta nests was also counted in experimental plots. The survey was conducted at 10:00 am in the sunny day.

The larvae and pupae of banana skipper E. torus and the living nymphs and adults of banana lace bug S. typica on all leaves of a banana plant were counted. Five banana plants in each small plot were surveyed, and three of six small plots were chosen randomly in every time of investigation. The survey was conducted once in the middle of each month from May to October, 2006. The study was conducted from May to October because it is the major occurring period of both pests. It also is the period that banana grow from the later seedling stage to young fruit stage.

\section{Data analyses}

All data were tested for normal distribution and homogeneity of variances by the Shapiro-Wilk test and Levene's test, respectively. Since all data were normal distribution, the analysis of variance followed by LSD mean comparison at $\alpha$ $=0.05$ was used to compare the number of fire ant mounds, trapped fire ant workers and populations of E. torus and $S$. typica among different plots and among different months using generalized linear model (GLM). All statistical analyses were conducted using SPSS, version 18.0 (SPSS Inc., Chicago, IL, USA).

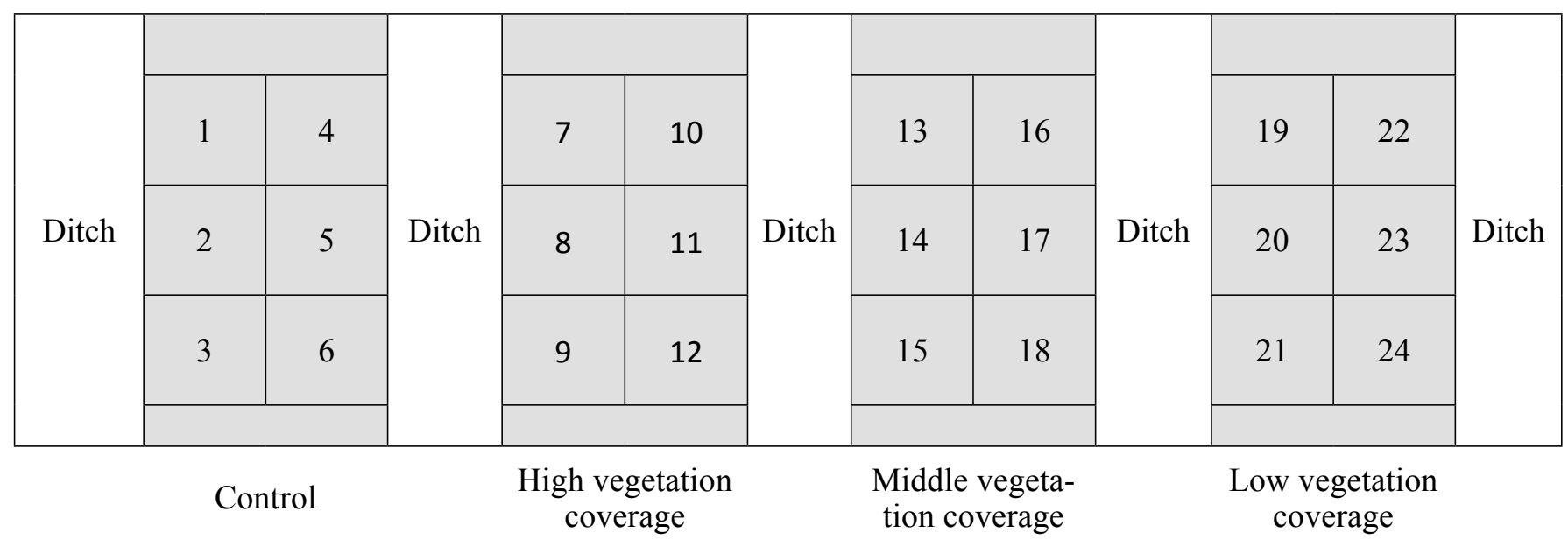

Fig 1. Schematic diagram about experimental site. 


\section{Results}

\section{Dynamic of $S$. invicta in banana plantation}

The numbers of $S$. invicta workers varied from May to October in high, moderate and low weed coverage experimental plots (Table $1, \mathrm{~F}=184.0, \mathrm{df}=17, \mathrm{P}<0.001$ ). The numbers of trapped workers increased after May and reach a peak in July. In July, 252 ants/trap, 275 ants/trap and 290 ants/ trap were collected in high, moderate and low weed coverage experimental plots, respectively. The numbers of trapped ants decreased in August and September and significantly increased again in October. The density of $S$. invicta nests also changed with time in different types of coverage experimental plots. The density of ant nests reached a peak in August in high weed coverage plots and reached the peak in June in moderate and low weed coverage plots $(\mathrm{F}=148.2, \mathrm{df}=17, \mathrm{P}<0.001)$.
Effect of S. invicta on banana skipper population $\boldsymbol{E}$. torus

In our investigation, E. torus populations in S. invicta infected plots were less than those in control from May to October (Table 2, $\mathrm{F}=150.07$, df $=8, \mathrm{P}<0.0001$ ). $E$. torus population reduction in high and moderate weed coverage plots were significantly higher than that in low weed coverage plot, but there was no significant difference between the high and moderate weed coverage plots from May to October $(\mathrm{F}=150.07, \mathrm{df}=8, \mathrm{P}<0.0001)$. The population of $E$. torus reduced by $21.6 \%-53.4 \%$, with an average $39.2 \%$ in high weed coverage plots. In moderate weed coverage plots, it was reduced by $13.4 \%-52.9 \%$, with an average $41.4 \%$. The population of E. torus also was reduced from $-5.4 \%$ to $33.5 \%$ in low weed coverage plots, with an average $19.2 \%$.

Table 1. Dynamics of $S$. invicta population in the three types of banana plantations.

\begin{tabular}{|c|c|c|c|c|c|c|}
\hline \multirow{2}{*}{$\begin{array}{c}\text { Date } \\
\text { (mm-yy) }\end{array}$} & \multicolumn{2}{|c|}{ Area of high vegetation coverage } & \multicolumn{2}{|c|}{ Area of moderate vegetation coverage } & \multicolumn{2}{|c|}{ Area of low vegetation coverage } \\
\hline & worker (ind./trap) & mound (ind./cell) & worker (ind./trap) & mound (ind./cell) & worker (ind./trap) & mound (ind./cell) \\
\hline $05-2008$ & $49.7 \pm 10.2$ & $8.0 \pm 1.7$ & $87.8 \pm 16.8$ & $8.7 \pm 0.7$ & $54.5 \pm 11.9$ & $10.3 \pm 1.3$ \\
\hline 07-2008 & $252.4 \pm 25.8$ & $19.0 \pm 1.5$ & $274.5 \pm 33.3$ & $14.7 \pm 0.7$ & $289.8 \pm 32.7$ & $8.7 \pm 0.9$ \\
\hline 08-2008 & $182.6 \pm 25.8$ & $20.3 \pm 2.2$ & $169.2 \pm 14.3$ & $11.0 \pm 1.5$ & $201.3 \pm 36.0$ & $9.3 \pm 0.9$ \\
\hline $10-2008$ & $378.2 \pm 27.4$ & $15.3 \pm 1.2$ & $219.8 \pm 48.1$ & $16.1 \pm 1.8$ & $361.0 \pm 32.4$ & $13.0 \pm 0.4$ \\
\hline
\end{tabular}

\section{Effect of $\boldsymbol{S}$. invicta on banana lacebug $\boldsymbol{S}$. typica populatione}

Population of S. typica in experimental plots was significantly lower than that in control plots from May to October (Table 3, $\mathrm{F}=257.29$, df $=8, \mathrm{P}<0.0001$ ), and reduction rate varied from $20.8 \%$ to $67.9 \%$. Reduction of $S$. typica population in the higher weed coverage plots was significantly lower than that in either moderate or lower weed coverage plots, and there are no significant difference in reduction of $S$. typica population between moderate and low weed coverage plots from May to October $(F=257.29$, $\mathrm{df}=8, \mathrm{P}<0.0001)$. The population of $S$. typica reduced significantly in May and September in high weed coverage plots. In July, population reduction rate of $S$. typica in moderate and low weed coverage plots reached the peak with $50.9 \%$ and $67.9 \%$, respectively.

Table 2. Effects of $S$. invicta invasion on population of banana skipper E. torus.

\begin{tabular}{|c|c|c|c|c|c|c|c|}
\hline \multicolumn{5}{|c|}{ Banana skipper density (ind./trunk) } & \multicolumn{3}{|c|}{ Reduction of banana skipper (\%) } \\
\hline $\begin{array}{c}\text { Date } \\
\text { (mm-yy) }\end{array}$ & $\begin{array}{l}\text { Control } \\
\text { area }\end{array}$ & $\begin{array}{l}\text { High vegetation } \\
\text { coverage }\end{array}$ & $\begin{array}{c}\text { Moderate vegetation } \\
\text { coverage }\end{array}$ & $\begin{array}{c}\text { Low vegetation } \\
\text { coverage }\end{array}$ & $\begin{array}{c}\text { High vegetation } \\
\text { coverage }\end{array}$ & $\begin{array}{c}\text { Moderate vegetation } \\
\text { coverage }\end{array}$ & $\begin{array}{c}\text { Low vegetation } \\
\text { coverage }\end{array}$ \\
\hline $05-2008$ & $8.6 \pm 1.3 \mathrm{a}$ & $6.2 \pm 0.8 \mathrm{~b}$ & $6.9 \pm 1.2 \mathrm{ab}$ & $7.1 \pm 1.4 \mathrm{~b}$ & 27.9 & 19.8 & 20.9 \\
\hline $06-2008$ & $11.9 \pm 0.4 \mathrm{a}$ & $6.8 \pm 0.5 \mathrm{c}$ & $10.3 \pm 0.4 b$ & $9.9 \pm 0.5 b$ & 42.9 & 13.4 & 16.8 \\
\hline $07-2008$ & $16.1 \pm 1.0 \mathrm{a}$ & $7.5 \pm 0.4 \mathrm{c}$ & $6.6 \pm 0.5 c$ & $10.7 \pm 0.6 b$ & 53.4 & 59.0 & 33.5 \\
\hline 08-2008 & $3.7 \pm 0.3 \mathrm{ab}$ & $2.9 \pm 0.2 b$ & $1.8 \pm 0.2 \mathrm{c}$ & $3.9 \pm 0.3 \mathrm{a}$ & 21.6 & 51.4 & -5.4 \\
\hline $09-2008$ & $3.4 \pm 0.2 \mathrm{a}$ & $1.9 \pm 0.1 \mathrm{c}$ & $1.6 \pm 0.2 \mathrm{c}$ & $2.6 \pm 0.2 b$ & 44.1 & 52.9 & 23.5 \\
\hline $10-2008$ & $3.1 \pm 0.1 \mathrm{a}$ & $1.7 \pm 0.2 \mathrm{c}$ & $1.5 \pm 0.2 \mathrm{c}$ & $2.3 \pm 0.1 b$ & 45.2 & 51.6 & 25.8 \\
\hline Average & & & & & $39.2 \pm 5.3$ & $41.4 \pm 8.7$ & $19.2 \pm 5.4$ \\
\hline
\end{tabular}

Note: Same letters indicated there is no significant difference in the same line $(\mathrm{P}<0.05)$ 
Table 3. Effects of $S$. invicta invasion on the population of banana lacebug S. typica.

\begin{tabular}{|c|c|c|c|c|c|c|c|}
\hline \multicolumn{5}{|c|}{ Banana lacebug (ind./trunk) } & \multicolumn{3}{|c|}{ Reduction of banana lacebug (\%) } \\
\hline $\begin{array}{c}\text { Date } \\
\text { (mm-yy) }\end{array}$ & Control area & $\begin{array}{l}\text { High vegetation } \\
\text { coverage }\end{array}$ & $\begin{array}{l}\text { Moderate vegetation } \\
\text { coverage }\end{array}$ & $\begin{array}{l}\text { Low vegetation } \\
\text { coverage }\end{array}$ & $\begin{array}{l}\text { High vegetation } \\
\text { coverage }\end{array}$ & $\begin{array}{l}\text { Moderate vegetation } \\
\text { coverage }\end{array}$ & $\begin{array}{c}\text { Low vegetation } \\
\text { coverage }\end{array}$ \\
\hline 06-2008 & $43.2 \pm 3.6 \mathrm{a}$ & $36.6 \pm 3.2 \mathrm{a}$ & $22.7 \pm 2.4 b$ & $20.7 \pm 2.2 b$ & 15.3 & 47.5 & 52.1 \\
\hline $07-2008$ & $5.3 \pm 0.4 \mathrm{a}$ & $3.8 \pm 0.5 b$ & $2.6 \pm 0.3 \mathrm{bc}$ & $1.7 \pm 0.3 \mathrm{c}$ & 28.3 & 50.9 & 67.9 \\
\hline 09-2008 & $15.5 \pm 1.6 \mathrm{a}$ & $8.0 \pm 1.3 \mathrm{~b}$ & $8.1 \pm 1.0 \mathrm{~b}$ & $9.8 \pm 1.0 \mathrm{~b}$ & 48.4 & 47.7 & 36.8 \\
\hline $10-2008$ & $14.6 \pm 1.3 \mathrm{a}$ & $16.3 \pm 0.9 \mathrm{a}$ & $8.6 \pm 0.8 \mathrm{~b}$ & $10.3 \pm 1.1 \mathrm{~b}$ & -11.6 & 41.1 & 29.3 \\
\hline Average & & & & & $17.8 \pm 8.3$ & $43.0 \pm 4.6$ & $39.2 \pm 7.2$ \\
\hline
\end{tabular}

Note: Same letters indicated there is no significant difference in the same line $(\mathrm{P}<0.05)$.

\section{Discussion}

Ants are important predators in agroecosystems (Risch \& Carroll, 1982; Way \& Khoo, 1992) and have been used in pest management (Huang \& Yang, 1987; Olotu et al., 2013), including the combination of ants in banana pest management programs banana (Sirjusingh et al., 1992; Gold et al., 2001). Our study provides evidence that $S$. invicta also can be an important biological control agent in banana plantation. $19.2 \%-41.4 \%$ of E. torus population and $17.8 \%-43.0 \%$ of S. typical population decreased when S. invicta appeared in three types of weed coverage banana plantations. Our results are consistent with previous studies indicating that $S$. invicta are particularly effective predators in agroecosystems (Ali et al., 1984; Bessin \& Reagan, 1989; Eubanks, 2001; Harvey \& Eubanks, 2004). Our investigation also gives support to the suggestion that $S$. invicta can play beneficial role in pests control although it was considered a serious pest in human health and crops (Vinson, 1997).

It showed the efficacy of $S$. invicta as biological control agent on E. torus was greater in the more complex habitat, it consistent with Harvey and Eubanks (2004)'s study. Harvey and Eubanks (2004) speculated that complex habitat resulted simpler plant architecture which can increase predator efficiency. It may be the same result to explain our result. However, controlling efficacy of S. invicta on S. typical is negative with the habitat complex. S. typical adults have wings and can fly, and nymphs are more actives than $E$. torus larvae and pupae. Complex habitant provides more hidden places for S. typical when they are attacked by S. invicta. Our results suggested that efficacy of $S$. invicta as a biological control agent was related to not only complexity degree of habitat, but also target pests.

Our results partially that $S$. invicta can be important and effective biological control agents. Although this study found that increasing habitat complexity only enhanced the efficacy of S. invicta on some target pests, intercropping may give more shelters to native species and reduce the negative effects of $S$. invicta on arthropod community. Future work should focus on the impact of $S$. invicta on banana plantation ecosystem and production since more data are needed to fully understand the ecological effects of the fire ant invasion, and the action of an effective biological control agent must result in decreased crop damage and increased yield (Symondson et al., 2002).

\section{References}

Ali, A.D., Reagan, T.E. \& Flynn, J.L. (1984). Influence of selected weedy and weed-free sugarcane habitants on diet composition and foraging activity of the imported fire ant (Hymenoptera: Formicidae). Environmental Entomology, 13: 1037-1041.

Bessin, R.T. \& Reagan, T.E. (1989). Cultivar resistance and arthropod predation of sugarcane borer (Lepidoptera: Pyralidae) affects incidence of deadhearts in Louisiana sugarcane. Journal of Economic Entomology, 86: 929-932.

Chen, L., Chen, Z., Chen, Z., Wang, C., Lu, H., Lu, R. \& Zhou, J. (2008). The interplanting technology of banana and mushroom. Edible Fungi, 30: 13-15.

Cook, J. (2003). Conservation of biodiversity in an area impacted by the red imported fire ant, Solenopsis invicta (Hymenoptera: Formicidae). Biodiversity and Conservation, 12: 187-195.

Eubanks, M.D. (2001). Estimates of the direct and indirect effects of red imported fire ants on biological control in field crops. Biological Control, 21: 35-43.

Fillman, D.A. \& Sterling, W.L. (1983). Killing power of the red imported fire ant [Hym.: Formicidae]: a key predator of the boll weevil [Col.: Curculionidae]. Biocontrol, 28: 339-344.

Gold, C.S., Pena, J.E. \& Karamura, E.B., (2001). Biology and integrated pest management for the banana weevil Cosmopolites sordidus (Germar) (Coleoptera: Curculionidae). Integrated Pest Management Reviews, 6: 79-155.

Guo, Z., Zeng, L., Fan, H., Yang, P., Tang, Z., Shi, Z., Bai, J., Guo, B. \& Duan C. (2012). Investigation on the species of banana insect pest and their damages in Yunan Province. 
Chinese Journal of Tropical Agriculture, 32: 42-45.

Harvey C.T. \& Eubanks, M.D. (2004). Effect of habitant complexity on biological control by the red imported fire ant (Hymenoptera: Formicidae) in collards. Biological Control, 29: 348-358.

Huang, H. \& Yang, P. (1987). The ancient cultured citrus ant. BioScience, 37: 665-671.

Ke, K., Li, R., Lin, W., Zeng, W., Xie, S., Zhou, J., Liang, J. \& Ye, C. (2012). Benefit evaluation of banana and pepper interplanting model. China Tropical Agriculture, 3: 50-52.

Lin, M., Liu, F., Peng, Z., Li, W., Xu, W. \& Wang, X. (2009). Survey and identification of pest insects on banana crop in Hainan. Southwest China Journal of Agricultural Sciences, 22: 1619-1622.

Liu, Y., Ding, W., Ca, Q., Liu, X., Li, W., Liang, Y. \& Li, H. (2015). Effects of Allium tuberosum interplanting and bioorganic fertilizer application on banana wilt disease and soil microorganisms. Journal of Agro-Environment Science, 34: 303-309.

Lu, Y.Y., Wang, L., Xu, Y., Zeng, L. \& Li, N. (2012). Correlation of the nest density and the number of workers in bait traps for fire ants (Solenopsis invicta) in southern China. Sociobiology, 59: 1197-1204.

Lu, Y.Y., Zeng, L. \& Liang, G. (2002). Advances in integrated management of major pests of banana in China. Wuyi Science Journal, 18: 276-279.

McDaniel, S.G., Sterling, W.L. \& Dean, D.A. (1981). Predators of tobacco budworm larvae in Texas cotton. Southwestern Entomologist, 6: 102-108.

Morrison, L.W. (2002). Long-term impacts of an arthropodcommunity invasion by the imported fire ant, Solenopsis invicta. Ecology, 83: 2337-2345.

Olotu, M.I., Du Plessis, H., Seguni, Z.S. \& Maniania, N.K., (2013). Efficacy of the African weaver ant Oecophylla longinoda (Hymenoptera: Formicidae) in the control of Helopeltis spp. (Hemiptera: Miridae) and Pseudotheraptus wayi (Hemiptera: Coreidae) in cashew crop in Tanzania. Pest Management Science, 69: 911-918.
Risch, S.J. \& Carroll, C.R. (1982). The ecological role of ants in two Mexican agroecosystems. Oecologia, 55: 114-119.

Sirjusingh, C., Kermarrec, A., Mauleon, H., Lavis, C. and Etienne, J., (1992). Biological control of weevils and whitegrubs on bananas and sugarcane in the Caribbean. Florida Entomologist, 75: 548-562.

Stiles, J.H. \& Jones, R.H. (2001). Top down control by the red mi ported fire ant (Solenopsis invicta). American Mid land Naturalist, 146: 171-185.

Symondson, W.O.C., Sunderland K.D. \& Greenstone, M.H. (2002). Can generalist predators be effective biocontrol agents? Annual Review of Entomology, 47: 561-594.

Vinson, S.B. (1997). Insect life: invasion of the red imported fire ant (Hymenoptera: Formicidae). American Entomologist, 43: 23-39.

Vogt, J.T., Grantham, R.A., Smith, W.A. \& Arnold, D.C. (2001). Prey of the red imported fire ant (Hymenoptera: Formicidae) in Oklahoma peanuts. Environmental Entomology, 30: $123-128$.

Wang, F.X., Wang, L., Li, X.N., Zeng, L., Lu, Y.Y., Wu, S.H. \& Zhu, J.Q. (2009). National standard: Guidelines for quarantine surveillance of Solenopsis invicta Buren. Beijing: Standards Press of China.

Way, M.J. \& Khoo, K.C. (1992). Role of ants in pest management. Annual Review of Entomology, 37: 479-503.

Wojcik, D.P., Allen, C.R., Brenner, R.J., Forys, E.A., Jouvenaz, D.P. \& Lutz, R.S. (2001). Red imported fire ants: impact on biodiversity. American Entomologist, 47: 16-23.

Zeng, L., Lu, Y.Y., He, X.F., Zhang, W.Q. \& Liang, G.W. (2005). Identification of red imported fire ant Solenopsis invicta to invade mainland China and infestation in Wuchuan, Guangdong. Chinese Bulletin of Entomology, 42: 144-148.

Zhou, S., Chen, Z., Zhang, Q., Kong, X., Zhong, Y., Lai, B., Chen, S. \& Wei M. (1993). The study on the transmission of banana rosette dwarf disease by Stephanitis typicus Distant. Journal of Chinese Electron Microscopy Society, 3: 238-241. 